Internationale Zeitschrift für

\section{Bauinstandsetzen}

und Baudenkmalpflege

9. Jahrgang, Heft 2, 2003
International Journal for Restoration of Buildings

and Monuments

Vol. 9, No. 2, 2003

\title{
Inhalt / Contents
}

Editorial

105

S. J. Meier und F. H. Wittmann

Hydrophobieren, eine Möglichkeit, die Restnutzungsdauer eines

Stahlbetonbauwerks mit korrodierender Bewehrung zu verlängern

Water Repellent Treatment, a Possibility to Extend the Remaining Service

Life of Reinforced Concrete Structures with Corroding Reinforcement

A. Gerdes und F. H. Wittmann

Hydrophobieren von Stahlbeton, Teil 2: Ausführung einer Hydro-

phobierung - Voruntersuchung, Durchführung und Qualitätssicherung

Water Repellent Treatment of Reinforced Concrete, Part 2: Procedure of Water

Repellent Treatment - Preliminary Tests, Execution, and Quality Assurance

A. Elena Charola

Authenticity in the Restoration of Monuments:

A Commented Report on the WTA Colloquium held

at the Katholieke Universiteit Leuven, March $14^{\text {th }}, 2003$

Authentizität beim Restaurieren von Baudenkmalen:

Bemerkungen zu einem WTA Kolloquium, das am 14. März 2003

an der Katholischen Universität in Leuven stattfand

G. M. E. Kamh

Evaluation of Seven Resins as Stone Surface Consolidants for four Limestone Facies using a Magneto-Structive Ultrasonic Technique Beurteilung der Wirksamkeit sieben unterschiedlicher Harze für die Oberflächenfestigung von vier Arten Sandstein unter Anwendung einer magneto-struktiven Ultraschallmethode

S. J. Meier und M. F. Bäuml

Zur Vermeidung von Rissen in Stahlbetonbauwerken

On the Avoidance of Crack Formation in Reinforced Concrete Structures 


\section{Aus der Praxis / Applications}

F. H. Wittmann und P. Piattella

Instandsetzung der Nordfassade des Predigerchores in Zürich

Restoration of the North Facade of the Predigerchor in Zurich

\section{Mitteilungen / Short Notes}

Energieeffizientes Bauen und Sanieren stützt die Bauwirtschaft

Innovative Lösungen im Fassadenbau

Totalsanierung bei laufendem Krankenhausbetrieb

Firmenmitteilungen / Companies Inform

\section{WTA-Flash}

Aus den WTA-Referaten

Neue WTA-Merkblätter 